\title{
Fracture detection using conventional well logging in carbonate Matulla Formation, Geisum oil field, southern Gulf of Suez, Egypt
}

\author{
Mohamed R. Shalaby ${ }^{1,2} \cdot$ Md Aminul Islam ${ }^{1}$
}

Received: 10 March 2016/ Accepted: 3 April 2017/Published online: 9 April 2017

(c) The Author(s) 2017. This article is an open access publication

\begin{abstract}
The non-availability of the advanced tools such as FMI and Borehole Televiewer has led to the use of conventional well logging methods in the examination of potential fractures and ultimately help in reservoir characterization and development. This study uses the said conventional well $\log$ data for fracture detection in the Upper Cretaceous Matulla Limestone Formation in the Geisum oil field, southern Gulf of Suez province, Egypt. Different applications have therefore been integrated together, which include the Secondary Porosity Index (SPI) with tri-porosity crossplot $(M-N)$, the natural gamma ray spectroscopy (NGS), the Dual Laterolog-MSFL logs separation, the litho-density and compensated neutron logs and the Variable Density log (VDL), which is based on the responses of the compressional and shear waves in front of fractured zones. Good secondary porosity is prevalent in the Matulla Formation with SPI values reaching maximum values of 21.5 and $15.1 \%$ in the studied wells. Three and six fractured zones have been recognized in Geisum A-2 and Tawila N-1 wells, respectively, based on SPI logs. Several of these proposed zones are supported by other tools such as NGS, photoelectric (Pe), and VDL and fracturability Index (FI). This integrated method using various conventional well $\log$ has produced results suggesting great probability in fracture identification in the carbonate Matulla Formation.
\end{abstract}

Mohamed R. Shalaby

mshalaby2004@yahoo.com

1 Petroleum Geoscience Department, Faculty of Science, University of Brunei Darussalam, Bandar Seri Begawan, Brunei Darussalam

2 Geology Department, Faculty of Science, Tanta University, Tanta 31527, Egypt
Keywords Gulf of Suez · Matulla Formation · Fractures · Conventional logging

\section{Introduction}

The complex nature of Egypt's geology makes the exploration and development of hydrocarbons extremely challenging since faults, fractures, evaporite sequences and radioactive minerals are common in Egypt. Petroleum exploration around the Gulf of Suez began just over 100 years ago at Ras Gemsa. The gulf has high hydrocarbon potential and is now a well-established oil province. This basin contains more than 80 oil fields, with reserves ranging from 1350 to $<1$ million bbl, in reservoirs of preCambrian to Quaternary age (Alsharhan 2003). It is presently ranked seventh in terms of production among the major grabens or rift basins of the world.

The Gulf of Suez in Egypt covers an area of about $25,000 \mathrm{sq} \mathrm{km}$. It extends along a north-northwest-southsoutheast orientation from latitude $27^{\circ} 30^{\prime} \mathrm{N}$ to $30^{\circ} 00^{\prime} \mathrm{N}$ and is located at the junction of the African and Arabian plates, where it separates the northeast African continent from the Sinai Peninsula (Alsharhan 2003). Its width varies from about $50 \mathrm{~km}$ at its northern end to about $90 \mathrm{~km}$ in the south, where it merges with the Red Sea (Bosworth and Mcclay K 2001).

This study aims to use the conventional logging tools to identify fracture zones in the Upper Cretaceous Matulla limestone formation in the southern part of the Gulf of Suez. The study area is located between latitudes $27^{\circ} 35^{\prime} \mathrm{N}$ to $27^{\circ} 39^{\prime} \mathrm{N}$ and longitudes $33^{\circ} 41.5^{\prime}$ to $33^{\circ} 44^{\prime} \mathrm{E}$ (Fig. 1). The Gulf of Suez was subjected to open marine transgression during the Upper Cretaceous up to Eocene (Omran 


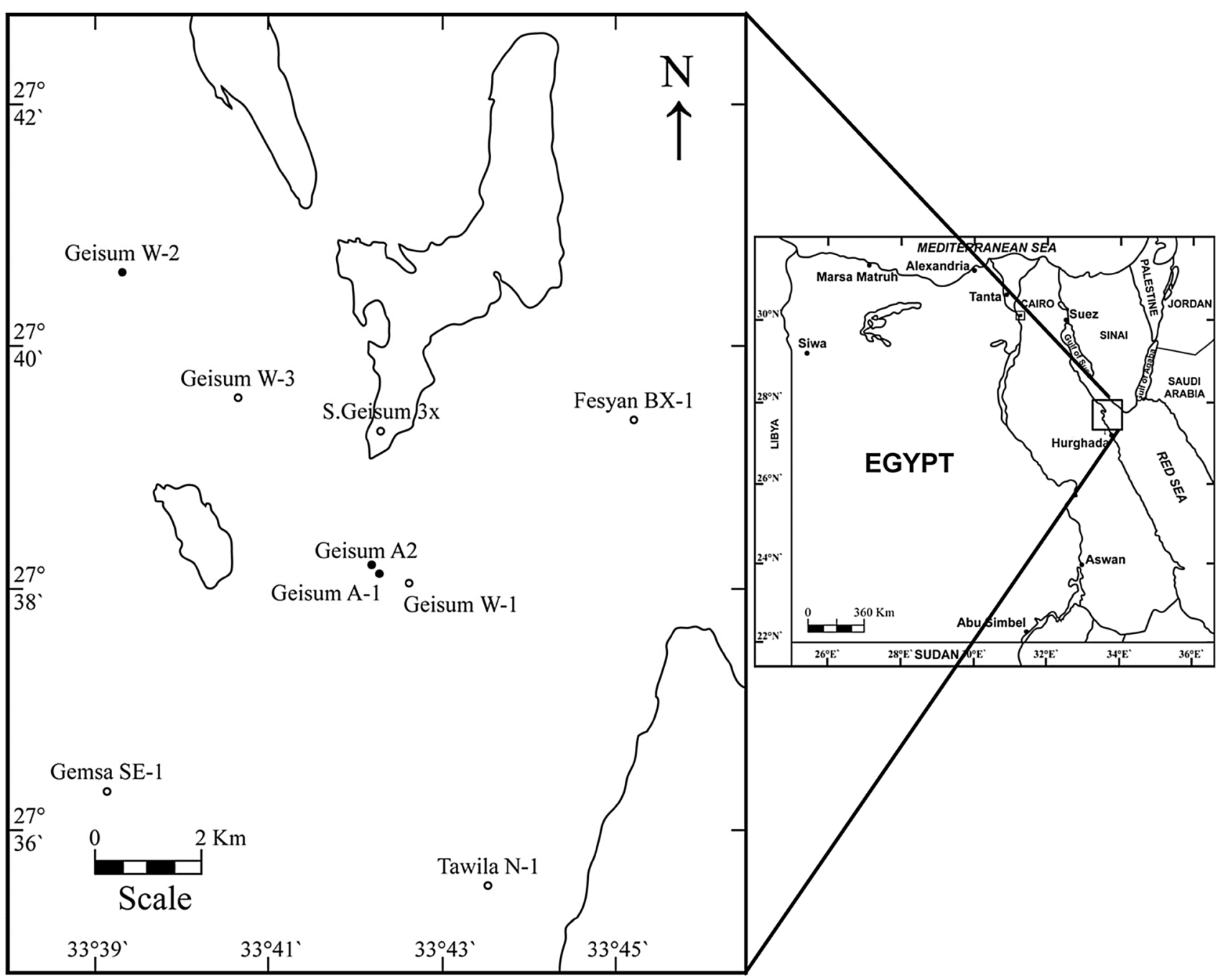

Fig. 1 Location map for the study area and well locations

and El Sharawy 2014). The Matulla Formation, which is widely distributed in the Gulf of Suez province, represents a slightly shallow marine facies.

Most carbonate reservoirs have complexity and heterogeneity as a result of their naturally fractured characteristic. These fractures have significant influence on the reservoir behavior and performance, such that they can produce complex paths for fluid movement, which impact reservoir characterization and production. Therefore, understanding fracture properties is very important (Roehl and Choduette 1985). Fractured zones can be detected both directly and indirectly using seismic sections, petrophysical logs, well tests, drilling mud loss history and core description (Thompson 2000; Nelson 2001; Martinez-Torres 2002; Dutta et al. 2007). Advanced logging methods for fracture analysis and detection, like the borehole acoustic televiewer, Formation Microscanner (FMS), Formation MicroImager (FMI) and Electric MicroImaging (EMI) are more accurate, but they naturally require higher cost and can only produce images at specific certain intervals. Conventional logging tools, on the other hand, can be assessed without interval limitations. Moreover, open and water- or hydrocarbon-filled fractures are also sensitive to conventional logging methods (Laongsakul and Durrast 2011).

\section{Geology of the study area}

The Gulf of Suez was initiated as the northern extension of Red Sea rifting, a continental rift zone that was active from the Late Oligocene to the end of Miocnee (Khalil and McKlay 2001). However, while the Red Sea has continued to develop to an oceanic sea floor spreading stage, the growth of the Dead Sea Transform east of the Gulf of Suez resulted in the gulf being cut off at a relatively early stage of rifting (Garfunkel and Bartov 1977; Garfunkel 1981; Tamsett 1984; Steckler and Ten Brink 1986; Feinstein 
et al. 1996). At present, the Dead Sea Transform plate boundary accommodates most of the motion between Africa and Arabia north of the Red Sea (Feinstein et al. 1996). During its brief post-rift history, the deepest part of the remnant rift topography has been filled by the sea, creating the Gulf of Suez. The gulf represents one of the most intensively faulted areas on the Earth (Fig. 2). Its present shape has been determined by fracture systems which were and possibly still are due to tectonic events caused by movements of the Nubian, Arabian and Sinai plates and the resulting rift trends, the (NNE-SSW) Aqaba Trend and $E-W$ (Tethyan) Trend (Dahy 2010). This tensional movement and subsidence resulted in the stretching and collapse of the crust. Subsidence moves potential source rocks to depths suitable for generation of hydrocarbon, whereas stretching movement can provide petroleum structural traps in the fault blocks for hydrocarbon accumulation. This is characteristic of rift basins (Lashin and Mogren 2012).

The lithostratigraphic units in the Gulf of Suez range in age from pre-Cambrian to Holocene. Figure 3 shows a simplified generalized stratigraphic section of the study area. Due to the Cenozoic rifting, the stratigraphic succession in the Gulf of Suez can divided into three lithostratigraphic megasequences (Plaziat et al. 1998): pre-rift, syn-rift and post-rift. These units vary in thickness, lithology, areal distribution, depositional environment and hydrocarbon importance (Alsharhan 2003).

The pre-rift stratigraphic sequence extended from Cambrian to Eocene. Deposition of pre-rift sediments was over a pre-Cambrian basement without noticeable tectonic deformation (Schutz 1994). Clastic Nubia sandstones (Paleozoic to Lower Cretaceous Albian) were deposited at the base, and this was followed by a stage of marine transgression (Omran and El Sharawy 2014). The marine transgression resulted in a sequence of carbonates and clastics interbeds. This Upper Cretaceous carbonates and clastics sequence is subdivided into the following formations from base to top: Raha, Abu Qada, Wata, Matulla, Brown Limestone and Suder (Chalk). The marine transgression continued into the lower Tertiary with the deposition of Paleocene and Eocene shales, carbonates, and marls. Eocene deposits determined the last stage of the transgression environment regime that has been dominated since Cenomanian (Omran and El Sharawy 2014). The synrift stratigraphic sequence is comprised of Oligocene and Miocene sediments. During Oligocene, continental or very shallow water conditions were common all over the Gulf region (Tromp 1950; Said 1962).

The focus of this study is the Lower Senonian Matulla Formation. It is $140 \mathrm{~m}$ thick on average, and its lithology is made up of marls, limestones, and shales, with several sandstone units. The Matulla Formation unconformably overlies the Wata Formation. The upper part of the Matulla Formation is generally represented by sandy shales that grade into shales toward the top. A sharp break marks the onset of a different depositional environment of radioactive, dark brown, organic-rich limestones of the overlying Brown Limestone Member of the Sudr Formation (Schutz 1994).

\section{Data and methodology}

\section{Types of available data}

Conventional logging tools have been obtained for two wells (Geisum A-2 and Tawila N-1) in the study area. For Geisum A-2 Well, the data set covers the interval from

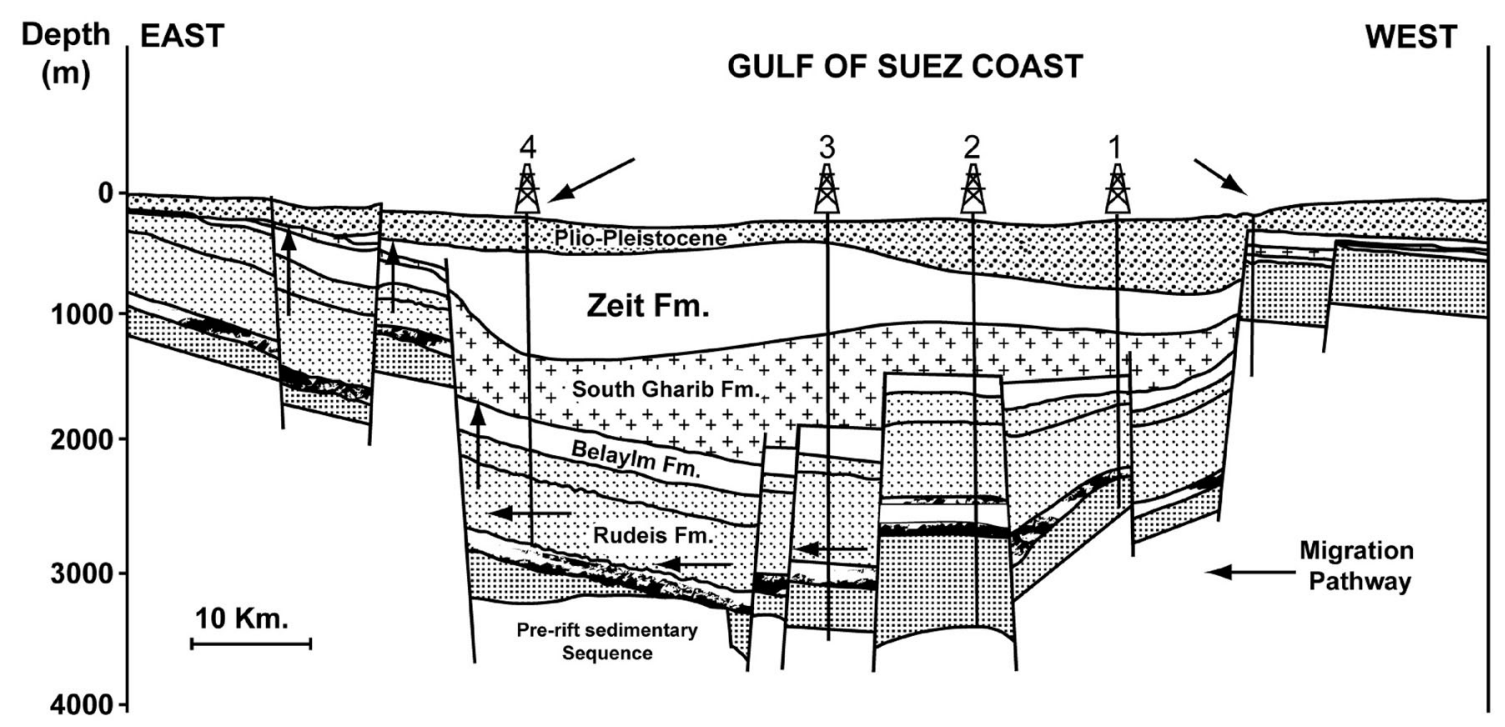

Fig. 2 Cross section showing the intensely faulted Gulf of Suez (Modified after Younes 2003) 
Fig. 3 Simplified stratigraphic section for the Gulf of Suez area, Egypt (modified Abd-El Naby et al. 2009)

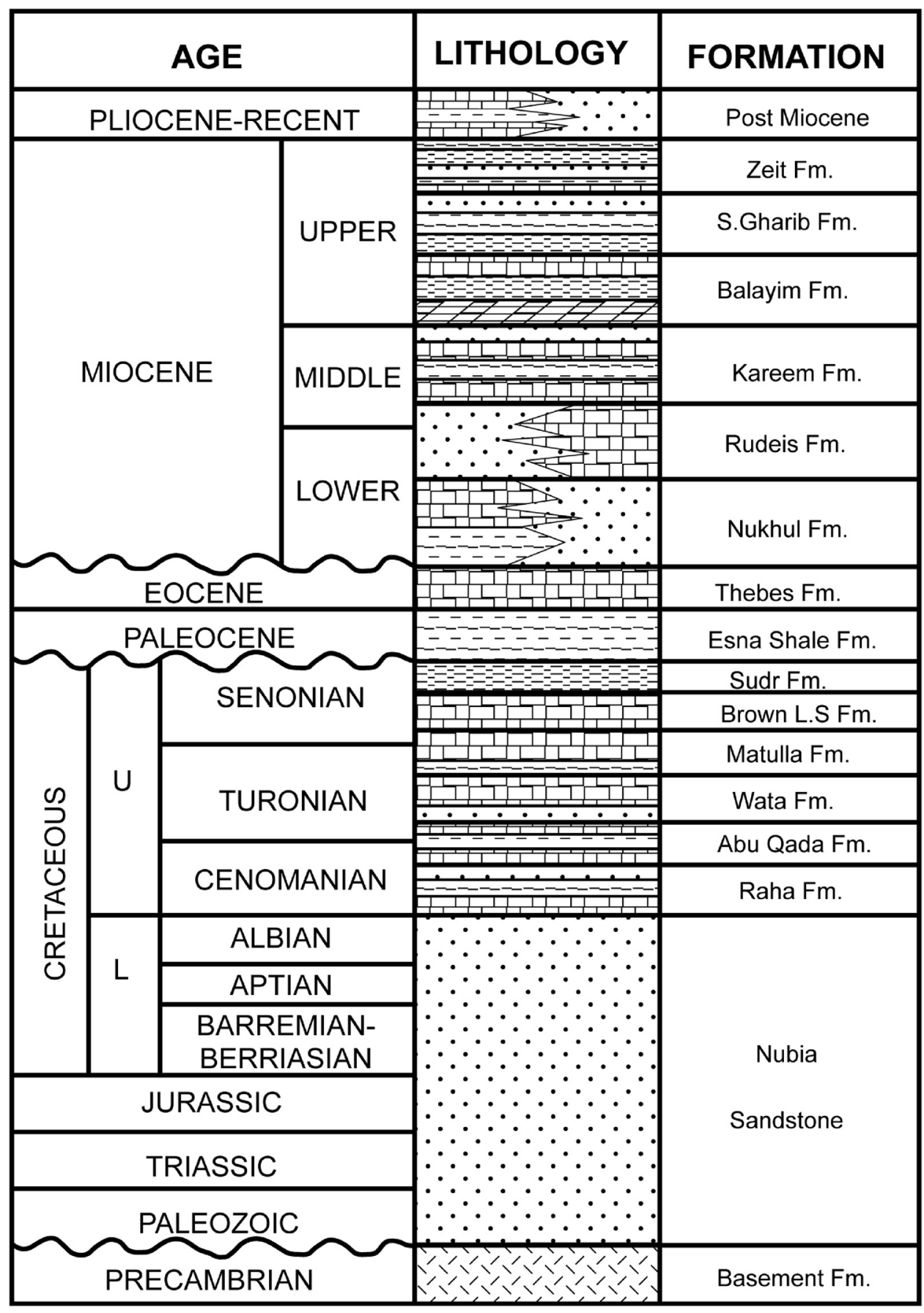

4640 to $4790 \mathrm{~m}$, with thickness of about $150 \mathrm{~m}$. It contains porosity logs (sonic, neutron and density), natural gamma ray spectroscopy (NGS) log, and litho-elastic properties log or Variable Density log (VDL). In the case of Tawila N-1 Well, the data set consists of porosity logs (sonic, neutron and density), natural gamma ray spectroscopy (NGS), litho-density compensated neutron log with photoelectric effect $(\mathrm{Pe})$, and the three resistivity log readings (LLd, LLs and MSFL), covering an interval of about $23 \mathrm{~m}$ from 3030 to $3053 \mathrm{~m}$.

\section{Methods of analysis}

Logging tools are designed to respond to different characteristics of the wellbore environment. With the exception of the acoustic and micro-resistivity image logs, which are considered the most direct and important tools to detect fractures and can, in favorable circumstances, see fractures directly, conventional logging tools results are indirectly affected by the presence of fractures. The detection of the open fracture network is of great importance in the Gulf of 
Suez area, particularly in the low porosity/permeability carbonates, due to the considerable increase in effective permeability provided by fractures. As in the case of faults, there is no single technique that can be relied upon to identify open fractures, but there are several tools that can be taken together to help in the recognition and understanding of fracture system. More details for all methods can be found in (Serra 1986, 1988; Ellis 1987; Ellis and Singer 2008; Crain 2010). The following is a series of brief descriptions on how the conventional logging tools can be used to estimate the fractured zones.

\section{Combination of litho-density (LDT) and compensated neutron (CNT)}

In most cases, the neutron and density logs respond to fractures filled with mud filtrate, by rapid excursions toward higher porosity. The density is highly influenced due to its better vertical definition and its sensitivity to associated borehole rugosity. Secondary porosity and lithology interpretation is an approach which can be applied using different tools and laboratory measurements. The more available and easiest method is to estimate total porosity and secondary porosity, as well as, to calculate the mineral content using well log data. The most useful ways are used by Wyllie et al. (1956, 1958), Dresser Atlas (1982), Asquith (1982), Bateman (1985), Schlumberger (1989). The total porosity deduced from the density-neutron combination-sonic porosity overlays (Figs. 4, 5) are particularly useful for determining the Secondary Porosity Index, SPI (vugs and fractures). In this work, the $M-N$ plot has been used (Fig. 6) for lithology identification and secondary porosity effect estimation, which may be related to the presence of fractures. This plot was first introduced by Burke et al. (1969) to help identify the mineral mixtures from sonic, density and neutron logs. We can estimate the lithology-dependent quantities $M$ and $N$. The $M$ and $N$ values are essentially porosity-independent parameters, where the crossplot provides lithology and secondary porosity identification.

The measurement of photoelectric effect $(\mathrm{Pe})$ is applied in one well (Tawila N-1) as shown in Fig. 7b. It is usually influenced by the barite, a compound in drilling mud. This barite mud may penetrate into open fractures, and this causes very large photoelectric effect, whereby very high and sharp peaks can be observed in front of mud-filled fractures. In this particular case, the well was drilled with barite mud, and in those conditions the Pe becomes a very useful indicator, since the barite concentrated in the fractures produces high spurious Pe readings.
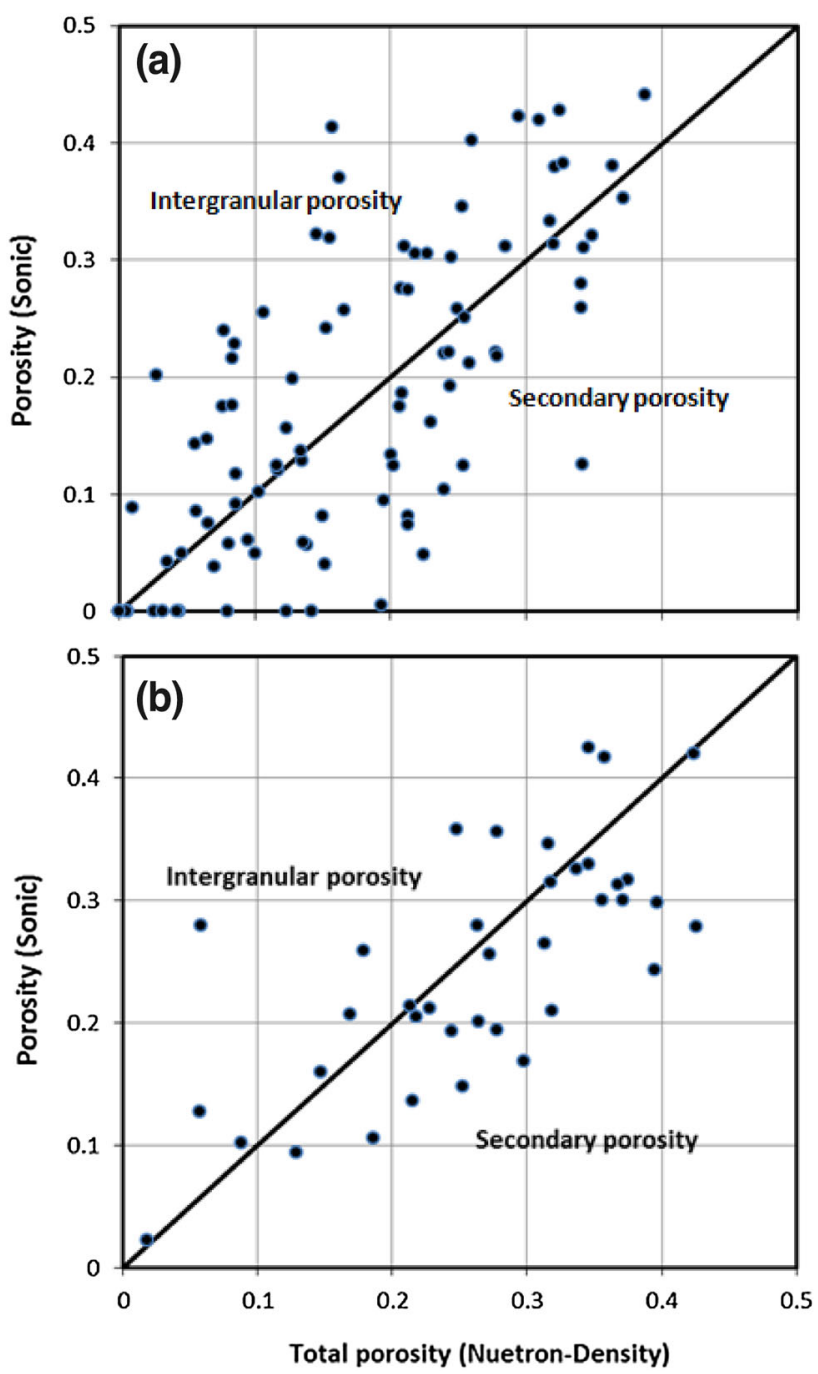

Fig. 4 The secondary porosity indicated from porosity crossplots in a Geisum A-2 and b Tawila N-1 wells

\section{Dual Laterolog-MSFL crossplot}

The combination of Dual Laterolog and Microspherically Focused Tool (DLT-MSFL) (Fig. 7a) is another effective resistivity tool for fracture identification, because the laterolog measurements will monitor the fractures parallel to the shallow formation resistivity (MSFL). The MSFL reads very high resistivity across low permeability matrix blocks, but gives anomalous low readings for fractures. For laterolog, the separation between the curves in a fractured zone is greater due to the invasion effects. Boyeldieu and Winchester (1982) and Sibbit and Faivre (1985) have used the characteristics of Dual Laterolog to estimate and detect the fractured zones. 


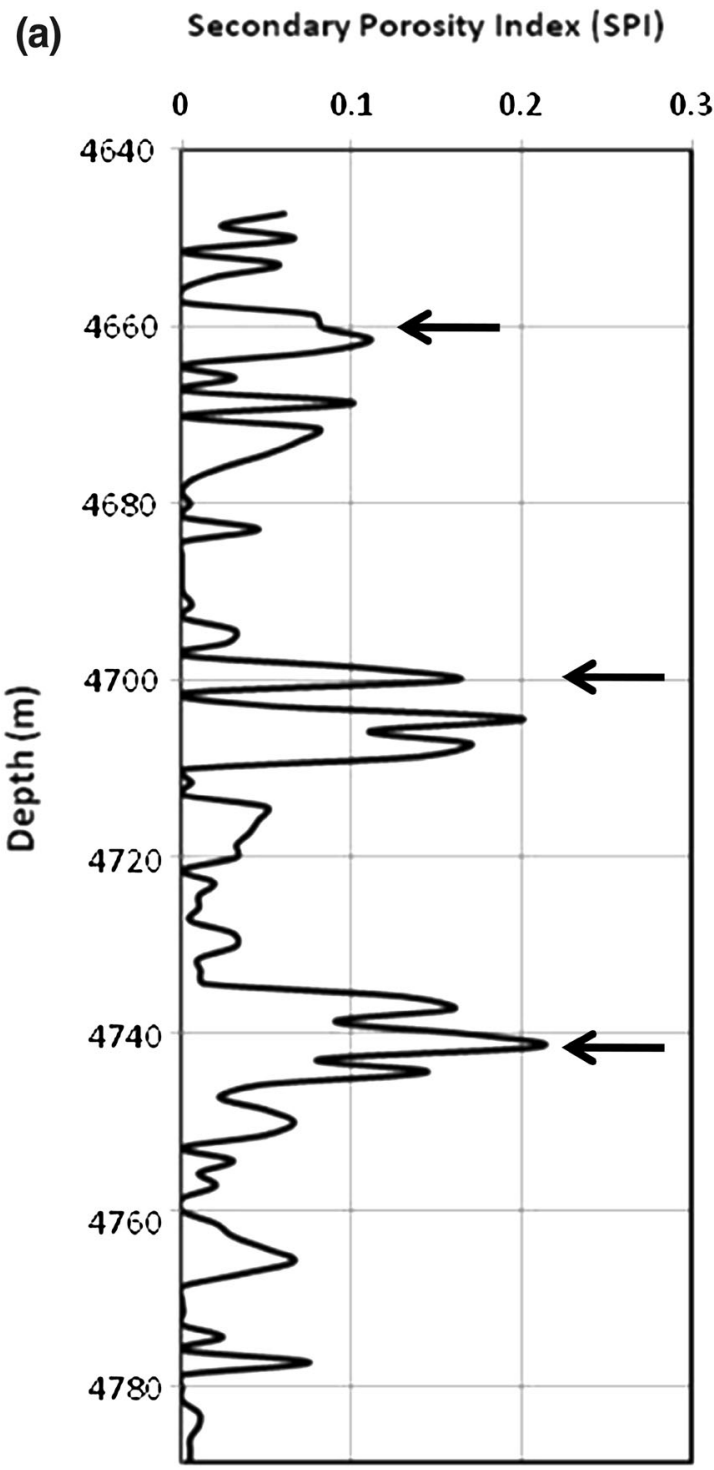

(b)

Secondary Porosity Index (SPI)

.3

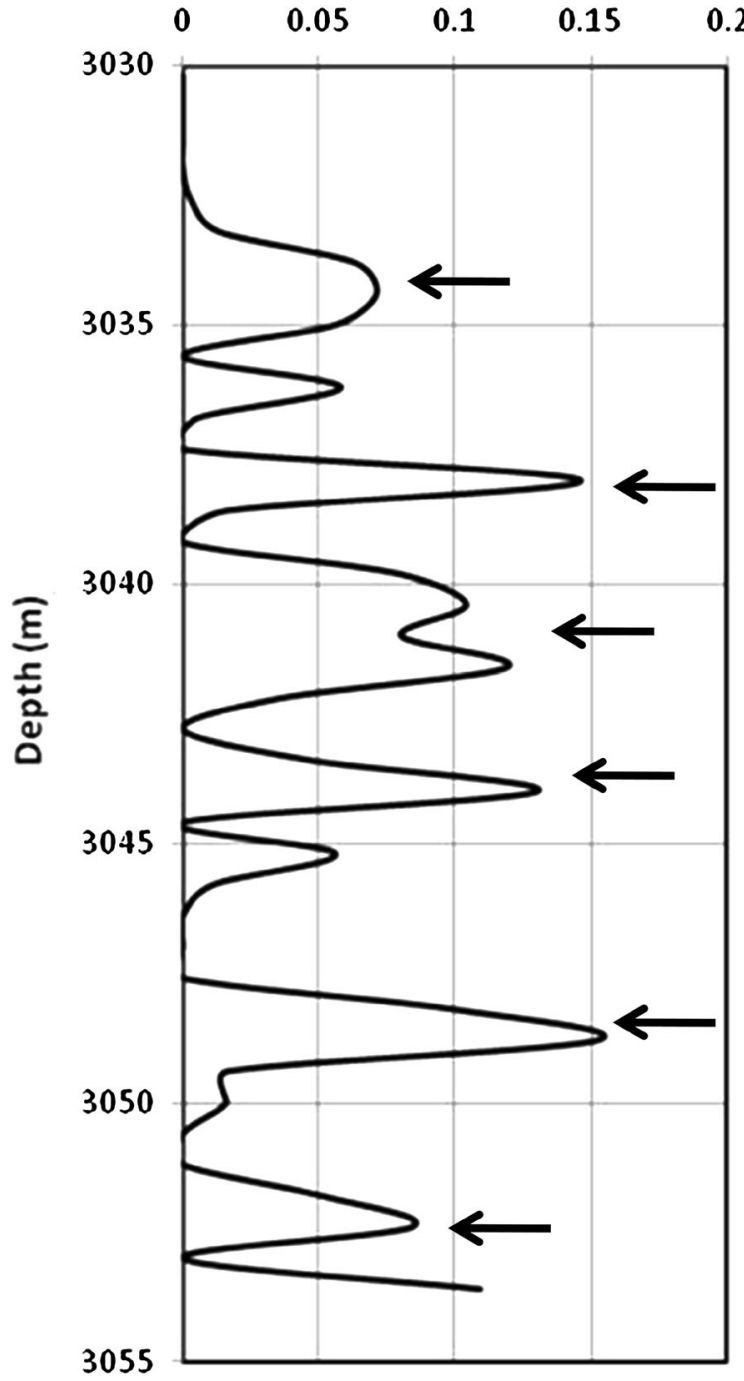

Fig. 5 Secondary porosity Index (SPI) showing probability for fractures, a in Geisum A-2 and b in Tawila N-1 wells

\section{Natural gamma ray spectroscopy (NGS)}

The natural gamma ray spectroscopy (NGS) tracks the natural gamma ray emission from the decays of Potassium, $40 \mathrm{~K}$, Thorium, 232Th, and Uranium, 238U, usually found in clay minerals. Most of the Uranium compounds are soluble in both water and hydrocarbon which makes it easier for them to penetrate into and precipitate in fracture zones with enhanced permeability. NGS, therefore, indicates more activity levels or more Uranium content in front of the fractured zones. Figures 8 and 9 are the crossplots of NGS versus depth in the two studied wells.
Variable density $\log (V D L)$

The Variable Density log (VDL) is one of the most important techniques that can be used to identify or propose fractures. VDL displays the acoustic waveform reaching a receiver. Using different processing steps, the $\log$ analyst can identify the compressional and shear waves. Fractures and formation discontinuities affect the transmission of acoustic energy, since they cross the borehole within the transmitter/receiver spacing, which can be recognized easily on the VDL. In fractured zones, the appearance of wave train recorded on the VDL shows sudden changes. The shear wave velocity $\left(V_{s}\right)$ is more 

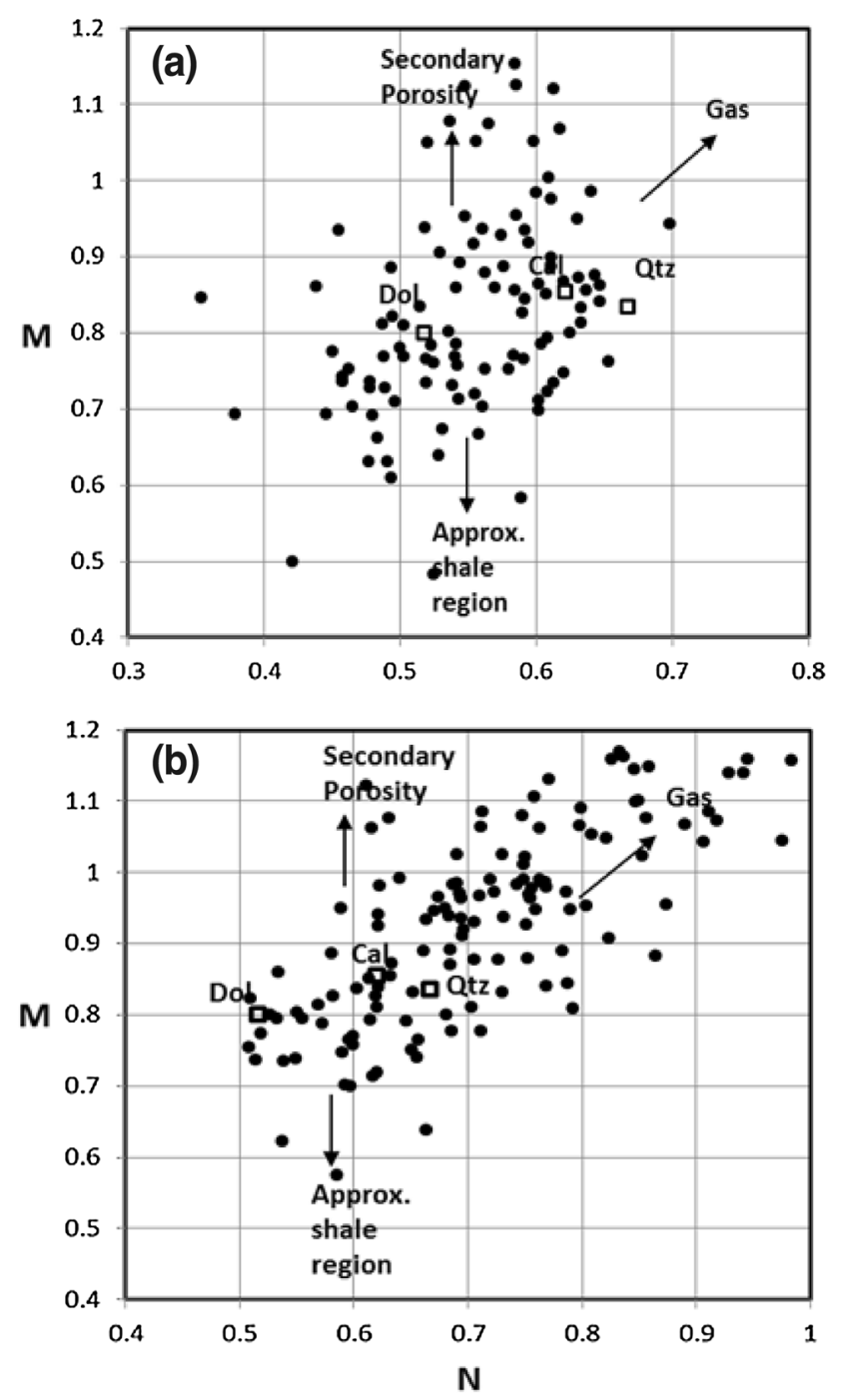

Fig. 6 The secondary porosity indicated from $M-N$ crossplots in a Geisum A-2 and b Tawila N-1 wells

affected by the fractures than the compressional wave velocity $\left(V_{p}\right) ; V_{s}$ shows apparent decrease while $V_{p}$ remains constant. Thus, by comparing $\Delta$ ts with $\Delta$ tc possible fractured zones can be identified or suggested where the $\Delta$ ts increases while $\Delta$ tc remains constant (Serra 1986).

Morris et al. (1963) and Cheung (1984) used the sonic $\log$, compressional and shear acoustic amplitudes for the location of fractures. Young's modulus $(E)$, shear modulus $(G)$, bulk modulus $(K)$, Poisson's ratio $(\sigma)$ and bulk density of sediment $(\rho)$ can be estimated using different equations based on the $V_{p}$ and $V_{s}$ (Dobrin and Savit 1988; Gardner et al. 1974; Hawkins and Whiteley 1979; McMahon 1980; Tezcan et al. 2006; Uyanik 2010).

Fracturability Index (FI) is a concept developed for hydrocarbon exploration, particularly useful for fracture placements and sweet spot identification in shale reservoirs. Jin et al. (2014) introduced three FI models: (1) the average product of normalized brittleness and rate of strain energy released, (2) the average between normalized brittleness and normalized fracture toughness, and (3) the average of normalized brittleness and normalized Young's modulus. In this study, different fracturability indices (FI) have been applied, based on the aforediscussed elastic properties, following the methods by Alzahabi et al. (2015), Shanks et al. (1976).

\section{Results and discussions}

\section{SPI and porosity crossplots}

The evaluation of porosity overlay is an essential parameter in studying the probability of fractured zones in the formation. In the following part, different porosity crossplots and overlays have been used to identify the probability of fractured zones in the limestone Matulla Formation. Figure $4 \mathrm{a}$ shows the porosity overlay between total porosity on $X$ axis and sonic porosity on $Y$ axis in Geisum A-2 Well. The plotted points are observed to be equally distributed between both groups but there are many notable points plotted in the secondary porosity zone, which may suggest that good secondary porosity is expected from the limestone of the Matulla Formation in Geisum A-2 Well. The Secondary Porosity Index (SPI) for the examined interval in Geisum A-2 Well (Fig. 5a) reaches up to a maximum value of $21.5 \%$ in some zones, with an average of $3.17 \%$. Based on the SPI log plot, three zones show increments in the plot and can therefore be proposed to be considered as fracture intervals. Following this hypothesis, the formation is likely subjected to fracturing process at the specified depths 4662, 4698-4710, and 4736-4746 m (Fig. 5).

In Tawila N-1 Well (Fig. 4b), the porosity crossplot between total porosity and sonic porosity also suggests the presence of abundant secondary porosities. The total porosity is observed to be higher than the sonic porosity in many zones. The Secondary Porosity Index (SPI) is plotted versus depth (Fig. 5b). Maximum SPI value records $15.1 \%$, with an average of $4 \%$. A total of six fractured zones are proposed in this formation. They are expected at depths of 3034, 3038, 3040-3042, 3044, 3048.5 and $3052 \mathrm{~m}$.

Figure 6a, b shows the $M-N$ crossplots in Geisum A-2 and Tawila $\mathrm{N}-1$ wells, respectively. It is noticed that most of the plotted points of the limestone of Matulla Formation are clustered mainly toward the calcite and dolomite points, indicating carbonate lithology. The presence of secondary porosity can be seen in both wells. Many points are shifted upward, indicating the effect of secondary porosity. This secondary porosity may be attributed to various reasons, but fracturing is one good possibility. In addition, there are some points that are shifted downward, 

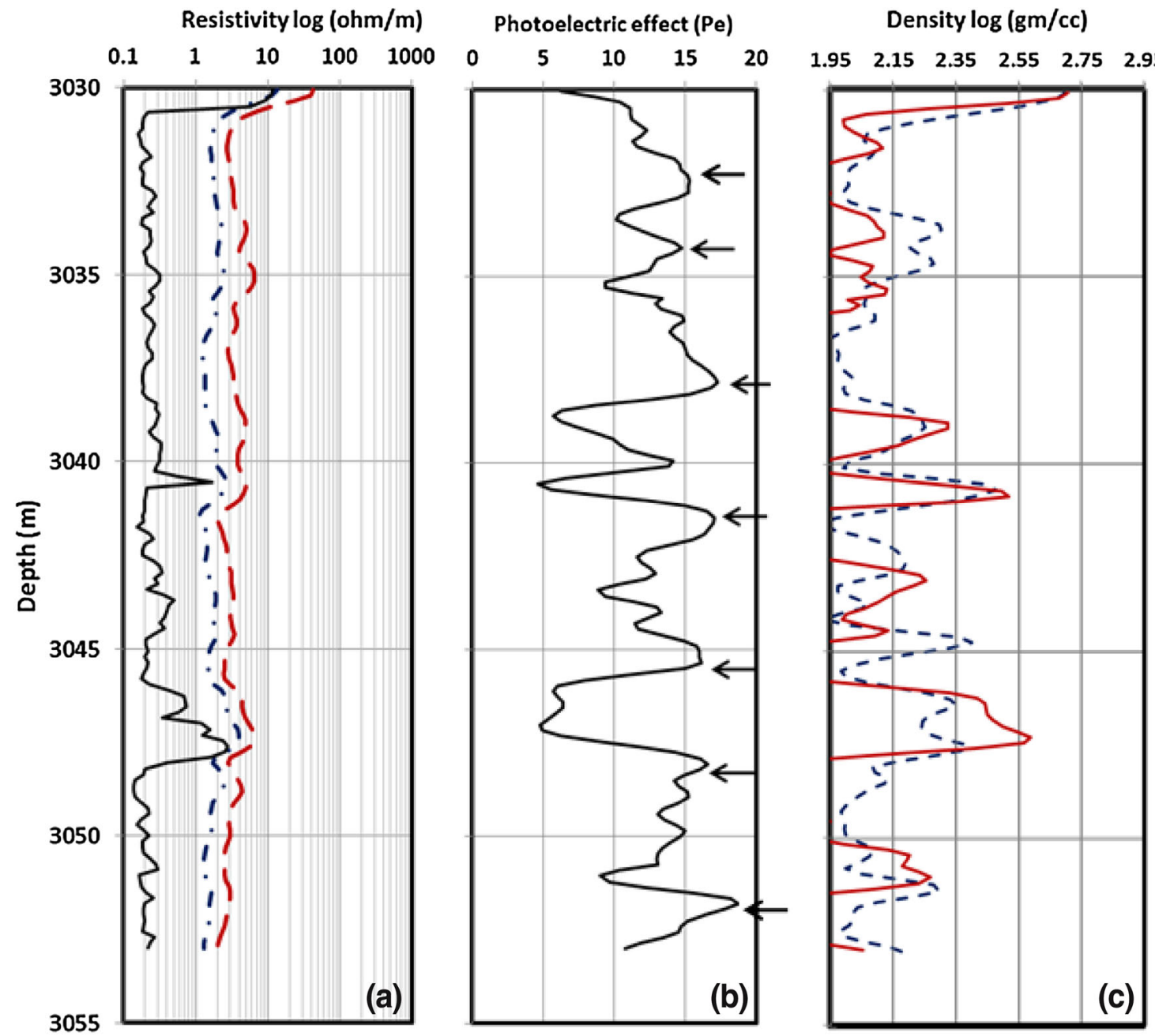

Fig. 7 Fractures indicated from well logging in Tawila N-1 Well, a Dual Laterolog-MSFL, separation indicating high permeable zone, b photoelectric effect (Pe) increases showing fracture zones,

indicating the shale effect, whereas some others are shifted upward right, which suggests the effect of gas.

\section{Resistivity, litho-density and compensated neutron $\operatorname{logs}$}

In Fig. 7, the Dual Laterolog-MSFL for Matulla Formation in Tawila N-1 Well is presented versus depth (Fig. 7a). It is observed that the MSFL reads very low values and simultaneously, a big separation is observed between the LLd and LLs curves. The latter can be interpreted as a result of fracture effect in the formation.

The litho-density and compensated neutron crossplot for the Matulla Formation in Tawila N-1 Well is presented in c neutron-density overlay sowing very low density and high neutron reading proposing fracture zones

Fig. $7 b, c$. The photoelectric capture measurement taken by Schlumberger litho-density tool (LDT) is very sensitive to barite, and so it can detect fractures that have been invaded by barite mud (Fig. 7b). In front of the fractured zones at the specified depths, the tool measures very high values of photoelectric effect $(\mathrm{Pe})$. The increase in Pe values indicates the presence of fractures within the formation. Sharp Pe peaks have been noticed at seven zones at 3032.5, 3034, 3036-3038, 3042, 3045, 3048-3050 and $3052 \mathrm{~m}$. Five out of seven of suggested fractured zones from SPI (3034, 3038, 3040-3042, 3048.5 and $3052 \mathrm{~m}$ from Fig. 5b are supported by the Pe result with good agreement with each others. Moreover, the presentation of the neutron-density overlay shows a sharp decrease in the formation matrix 


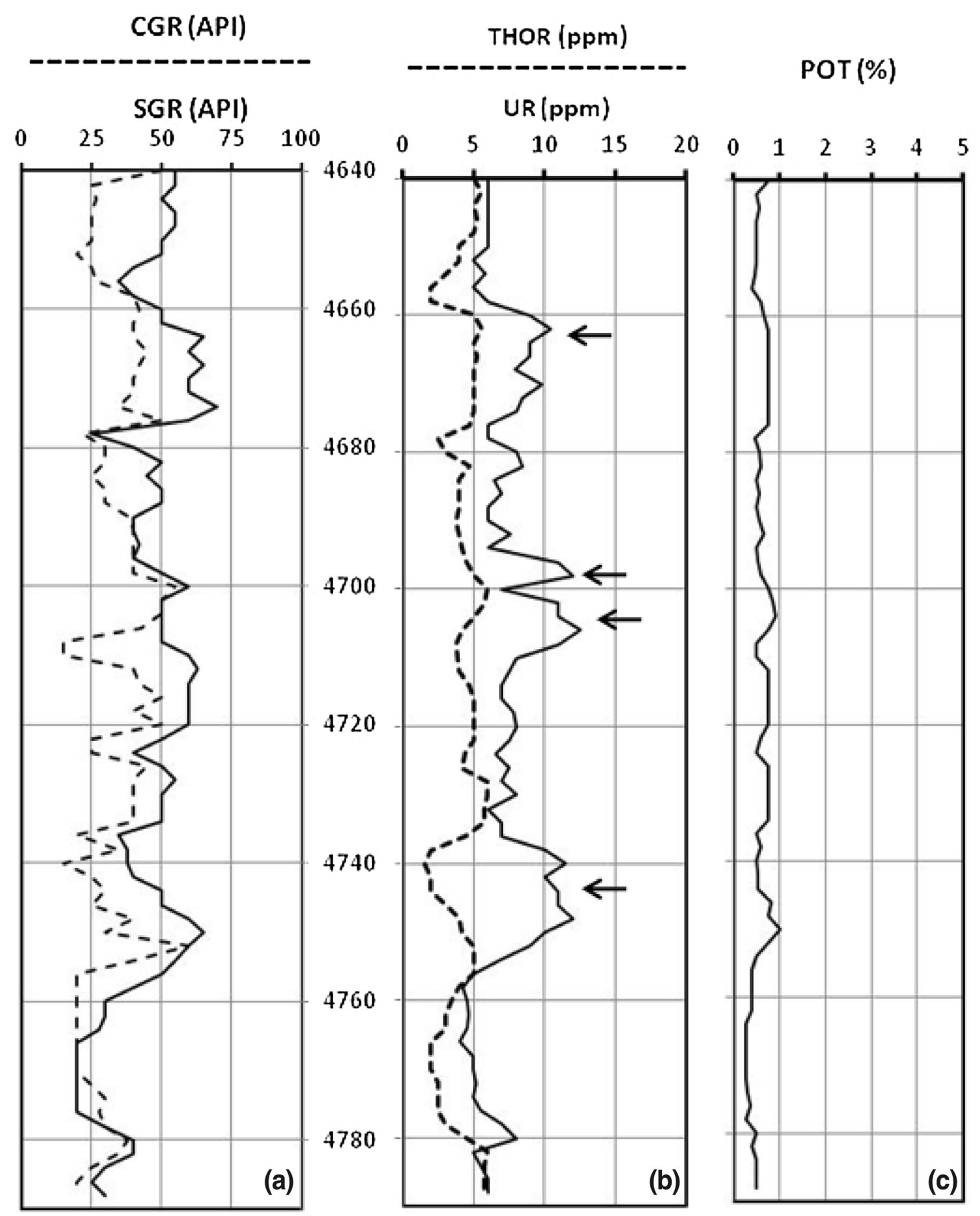

Fig. 8 Fractures probability as indicated from natural gamma ray spectroscopy in Geisum A-2 Well

density, which is accompanied by another sharp increase in the neutron log reading. This can be interpreted as a result of invasion of mud filtrate into the formation fractures, which destroys the readings of formation density $\log$. Simultaneously, the plot also indicates that the neutron log has been dramatically increased as it is measuring within the fractures occupied mud (Fig. 7c).
Natural gamma ray spectroscopy (NGS) log

The standard gamma ray tool, or the spectroscopy of the natural gamma ray, will show increased activity levels or increased uranium content in front of the fractured zones. This feature can be observed when the precipitation of uranium occurs in the fracture system, which may be aided 


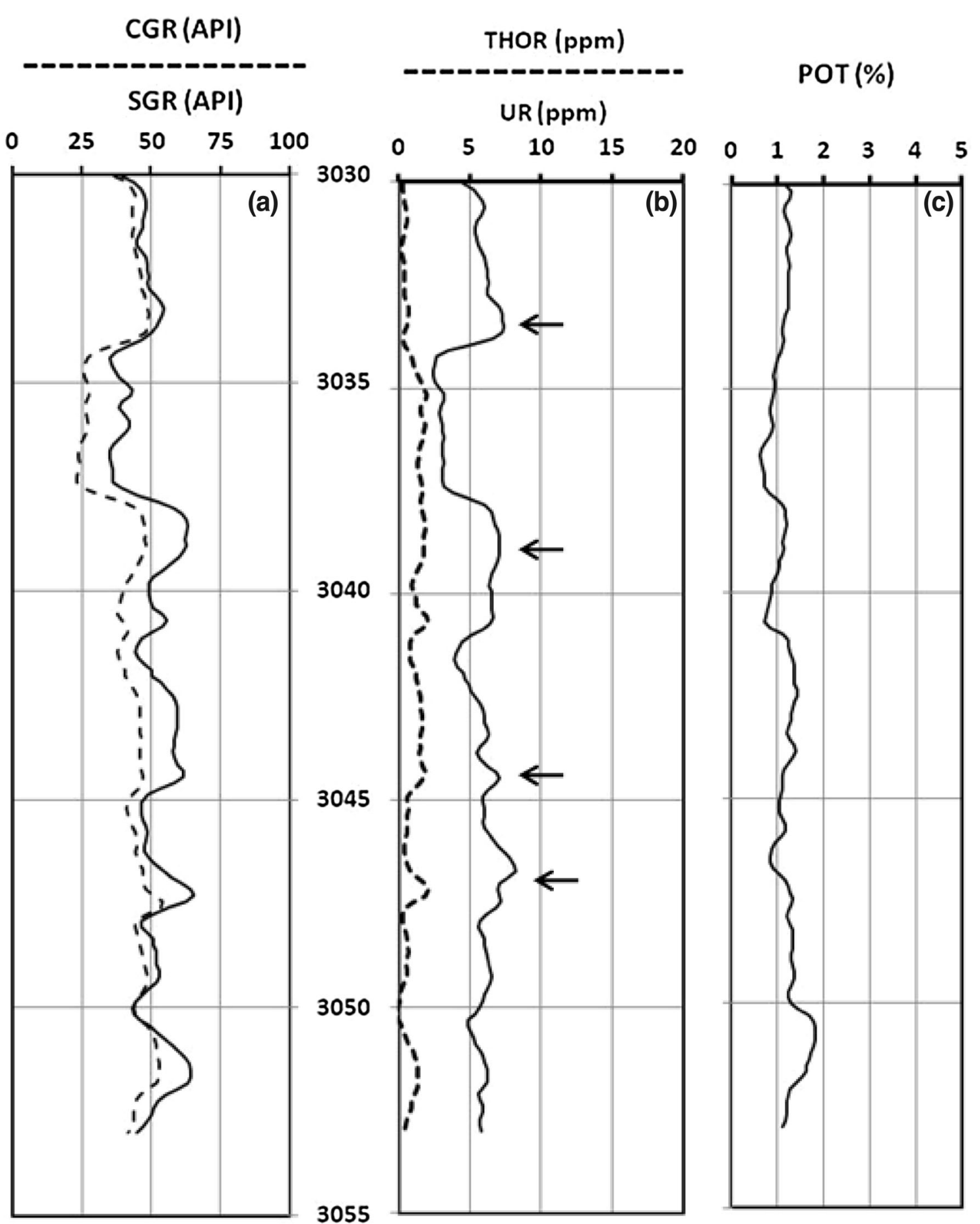

Fig. 9 Fractures probability as indicated from natural gamma ray spectroscopy in Tawila N-1 Well

by the circulation of fluids. Figures 8 and 9 show the natural gamma ray spectroscopy crossplots for Matulla Formation in Geisum A-2 and Tawila N-1 wells, respectively. In these two figures, it is observed the radioactivity increases in the formation. The level of increased uranium content is clearly observed, while no apparent peaks are observed for thorium and potassium. In Fig. 8b, uranium peaks are observed in the Matulla Formation in the Geisum 2-A Well at three zones at depths 4662, 4698-4710 and 4736-4746 m, which is in good and perfect agreement with the fracture intervals identified by the aforementioned SPI (Fig. 5a). Therefore, this further increases the possibility of finding fractures in these zones. Figure $9 \mathrm{~b}$ shows that relatively slight increase in uranium peaks at several zones in 
Tawila N-1 Well. The increment can be seen in three zone intervals as follow; at depths 3030-3034, 3038-3041, and 3044.5-3047. Noticeably, the intervals are not sharp peaks, but the slight increase may indicate fracture probabilities. It can be seen that several fractured zones obtained from SPI results (3034, 3038, 3040-3042, $3044 \mathrm{~m}$ from Fig. 5b are supported by this NGS result. The presence of uranium peaks along those intervals together with constant thorium and potassium radioactivity increases the probability of the presence of fractured zones within the formation.

\section{Variable density log (VDL)}

Variable Density log data in Geisum A-2 Well were available for analysis and interpretation (Fig. 10). The compressional and shear waves ( $\Delta \mathrm{tc}$ and $\Delta \mathrm{ts}$ ) have been recognized and used for fracture evaluation. Poisson's ratio $(\sigma)$ and fracturability index (FI) have been determined to detect the possibility of fracture occurrences in the formation. Figure 10 represents the analyzed section of the Variable Density log (VDL). The resultant fracturability Index (FI) is based on two methods, by Alzahabi et al. (2015), Shanks et al. (1976), using the elastic properties (Young's modulus, shear modulus, bulk modulus, Poisson's ratio and bulk density of sediment) derived from the compressional and shear velocities $\left(V_{p}\right.$ and $\left.V_{s}\right)$. The FI log based on Alzahabi et al. (2015) shows six promising fracture zones, at 4656-4668, 4682, 4694, 4702, 4720 and 4734-4762 m (Fig. 10b), while the FI based on Shanks et al. (1976) (Fig. 10c) shows five possible zones at intervals 4656-4672, 4698, 4716, 4722 and 4731-4760 m (Fig. 10b). Both FI log results support all three proposed
Poisson's Ratio

0.1

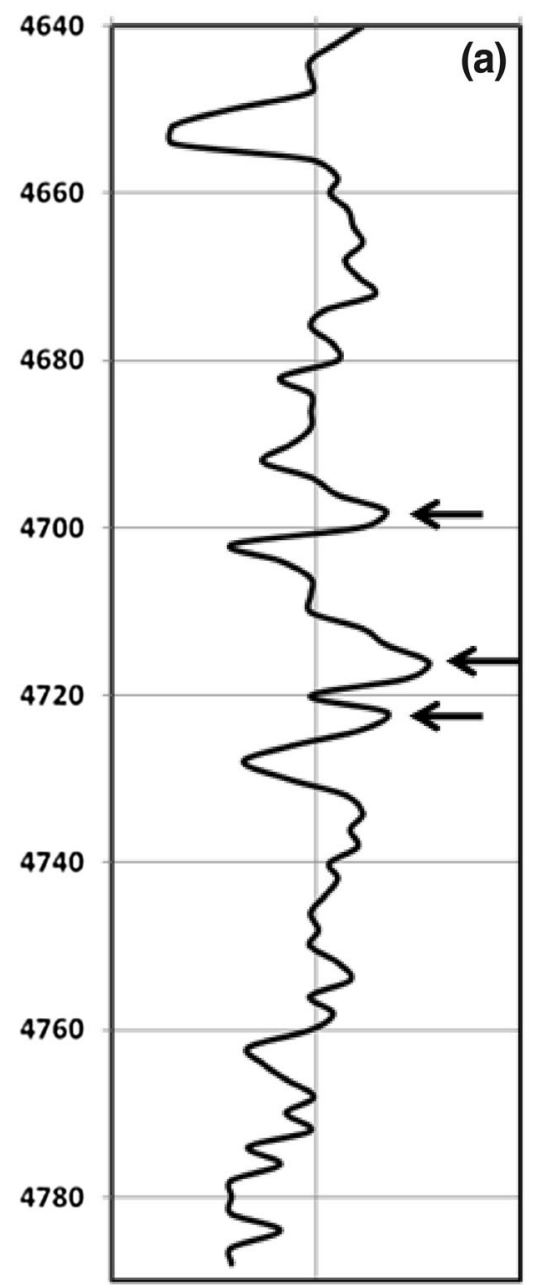

Fracturability Index (FI) (Alzahabi et al. 2015)

0.3

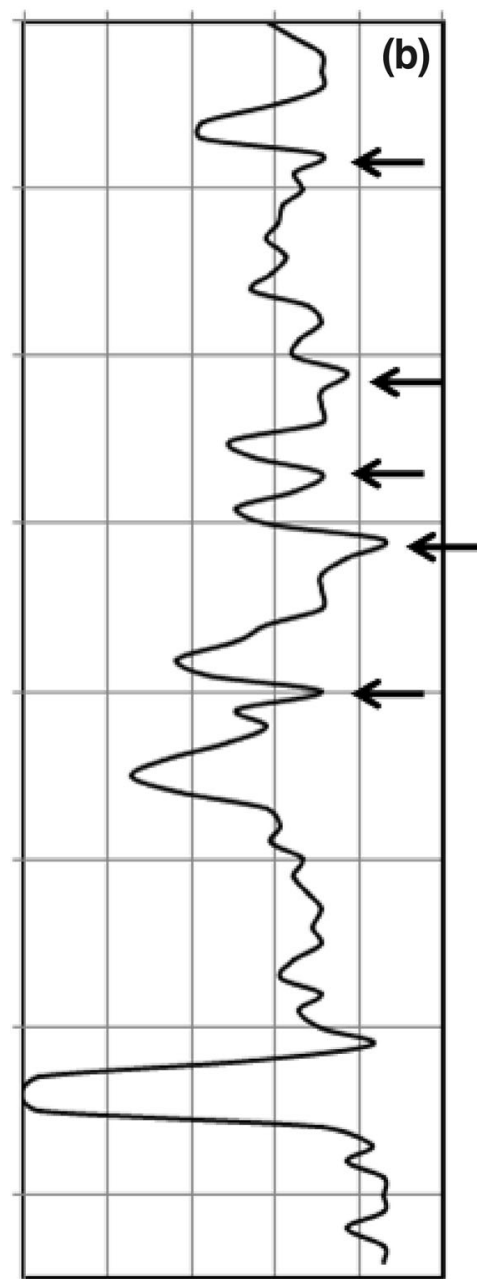

Fracturability Index (FI) (Shanks et al. 1976)

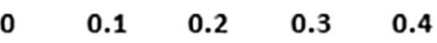

Fig. 10 Fractures indicated by shear wave velocity and fracturability index (FI) obtained from Variable Density log data (VDL) in Geisum-A2 Well 
fracture zones obtained from SPI and NGS results, at 4662, 4698-4710 and 4736-4746 m (Figs. 5a, 8b). There are other additional peaks or zones observed in each FI method. For the Alzahabi et al. (2015) method, the additional intervals include 4682, 4694 and $4720 \mathrm{~m}$ (Fig. 10b), whereas the Shanks et al. (1976) method shows two additional zones at 4716 and $4722 \mathrm{~m}$ (Fig. 10c), which are not previously supported by SPI and NGS results. These intervals may be as a result of other factors that are not explained by the mentioned tools.

From the complete analysis of all the conventional logging tools used in this study, it can be concluded that the Matulla Formation is characterized by the presence of fractures at some specific zones. There is general agreement between the results obtained from the analysis of disparate different tools.

\section{Conclusions}

The main objective of this study was to use the conventional well logging tools to predict the fractures in the Upper Cretaceous limestone of the Matulla Formation in the southern part of the Gulf of Suez. Well log data including sonic, density, neutron, natural gamma ray spectroscopy, photoelectric effect and variable density log were analyzed and interpreted to estimate and evaluate the fractures in the formation.

Good secondary porosity has been observed in the $M-$ $N$ crossplots, and the Secondary Porosity Index (SPI) reflects good values in many zones. The SPI indicates the probability of fractured zones at three and six intervals in Geisum A-2 and Tawila N-1 wells, respectively. For Geisum A-2 Well, the natural gamma ray spectroscopy (NGS), as indicated by the uranium peaks, perfectly correspond and support the suggested fractured intervals from the previous tools. Fractures in this Geisum A-2 Well have also been detected using the Variable Density $\log$ (VDL), which is based on the responses of the compressional and shear waves in front of the fractured zones. The study of litho-elastic properties and comparison between the $\Delta \mathrm{ts}, \Delta \mathrm{tc}$ and the fracturability indices (FI) indicate that the formation may be characterized by fractured zones, which is in good agreement as specified by other conventional tools. For Tawila N-1 Well, the proposed fractured zones indicated by NGS log are supported by the SPI results. The photoelectric capture effect also give considerable $\mathrm{Pe}$ values and supports several suggested fractured zones indicated by other tools. All these observations and findings can be directly related to the probability of presence of fractures in the formation.

\section{Recommendations}

Future recommendation for this research study includes correlation with published data for a more sound conclusion. The study has represented a more theoretical approach, with positive correlations from the techniques and data used; hence, the availability of more data would produce an improved quality of study.

Acknowledgements The authors thank the Egyptian General Petroleum Corporation (EGPC), Egypt, for providing the data used in this study. Many thanks are also extended to the University of Brunei Darussalam for giving all support and assistance to complete this research. I am the corresponding author for this study and I have to declare that there is no any sort of conflict of interest for myself and even for my co-author.

Open Access This article is distributed under the terms of the Creative Commons Attribution 4.0 International License (http:// creativecommons.org/licenses/by/4.0/), which permits unrestricted use, distribution, and reproduction in any medium, provided you give appropriate credit to the original author(s) and the source, provide a link to the Creative Commons license, and indicate if changes were made.

\section{References}

Abd-El Naby A, Abd El-Aal M, Kuss J, Boukharay M, Lashin A (2009) Structural and basin evolution in Miocene time, Southwestern Gulf of Suez, Egypt. Neues Jahrbuch für Geologie und Paläontologie-Abhandlungen, Germany 251(3):331-353

Alsharhan SA (2003) Petroleum geology and potential hydrocarbon plays in the Gulf of Suez Rift Basin, Egypt. AAPG Bull $87: 143-180$

Alzahabi A, Soliman MY, Bateman RM, Asquith G (2015) Fracturability index maps for fracture placement in shale plays. Hydraul Fract J 2(1):8-18

Asquith GB (1982) Basic well log analysis for geologists, AAPG. Methods in Exploration Series. 216p

Bateman RM (1985) Open-hole log analysis and formation evaluation. International Human Resources Development Corperation, Boston, p 647

Bosworth W, Mcclay KR (2001) Structural and stratigraphic evolution of the Gulf of Suez rift, Egypt: a synthesis. In: Ziegler PA, Cavazza W, Robertson AHFR, Crasquin-Soleau S (Eds) PeriTethyan Rift/Wrench Basins and Passive Margins. Mémoires du Muséum national d'Histoire naturelle, 6, 186:567-606

Boyeldieu C, Winchester A (1982) Use of the Dual Laterolog for the evaluation of the fracture porosity in hard carbonate formations. In: Offshore South East Asia 1982 conference, 9-12 Feb. Singapore

Burke JA, Campbell RL, Schmidt AW (1969) The Litho-porosity Crossplot. Log Anal (SPWLA) 10(6):25-43

Cheung PH (1984) Fracture detection using the sonic tool. In: SAIDSPWLA, 9th Europ Intern Form Eval Trans, Paris 42 pp

Crain ER (2010) Crain's petrophysical handbook. Mindware Ltd., Canada

Dahy SA (2010) Study on seismicity and tectonic setting in the Northeastern Part of Egypt. Res J Earth Sci 2(1):08-13

Dobrin MB, Savit CH (1988) Introduction to geophysical prospecting, 4th edn. McGraw-Hill, New York 
Dresser Atlas (1982) Well logging \& interpretation techniques: the course for home study. Dresser Industries Inc.

Dutta P, Singh SK, Al-Genai J, Akhtar A, Akbar M (2007) A novel approach to fracture characterization utilizing borehole seismic data. In: 15th SPE Middle East Oil \& Gas Show and Conference, Bahrain: Paper SPE, 105427. 6

Ellis DV (1987) Well Logging for Earth Scientists. Elsevier, New York, p 532

Ellis DV, Singer JM (2008) Well logging for Earth Scientists, 2nd edn. Springer, Berlin

Feinstein S, Kohn BP, Steckler MS, Eyal M (1996) Thermal history of the eastern margin of the Gulf of Suez, I. reconstruction from borehole temperature and organic maturity measurement. Tectonophysics 266:203-220

Gardner GHF, Gardner LW, Gregory AR (1974) Formation velocity and density-the diagnostic basic for stratigraphic trap. Geophysics 39:770-780

Garfunkel Z (1981) Internal structure of the Dead Sea leaky transform (rift) in relation to plate kinematics. Tectonophysics 80:81-108

Garfunkel Z, Bartov Y (1977) The tectonics of the Suez Rift. Geol Surv Isr Bull 71:44

Hawkins LV, Whiteley RJ (1979) Estimation of rippability and excavation conditions in calcrete deposits with seismic refraction methods. In: 1st Geophysical conference Australian Society of Exploration Geophysicists, 10:223-224

Jin X, Shah SN, Roegiers JC (2014) Fracability evaluation in shale reservoirs-an integrated petrophysics and geomechanics approach. In: SPE-168589 SPE hydraulic fracturing technology conference held in The Woodlands, TX. Feb. 4-6

Khalil S M, McClay K R (2001) Tectonic evolution of the NW Red Sea-Gulf of Suez rift system. In: Wilson RCL, Whitmarsh RB, Taylor B, Froitzheim N (eds) Non-volcanic rifting of continental margins: a comparison of evidence from land and sea. Special Publication. 187. Geological Society of London. ISBN 978-186239-091-1, pp. 453-473

Laongsakul P, Durrast H (2011) Characterization of reservoir fractures using conventional geophysical logging. Songklanakarin J Sci Technol 33(2):237-246

Lashin A, Mogren S (2012) Total organic carbon enrichment and source rock evaluation of the lower miocene rocks based on well logs: October Oil Field, Gulf of Suez-Egypt. Int J Geosci 3:683-695

Martinez-Torres LP (2002) Characterization of naturally fractured reservoirs from conventional well logs. M.Sc. Thesis, University of Oklahoma. USA

McMahon BK (1980) Engineering seismic refraction surveys over Elura. Explor Geophys 11:180-182

Morris RL, Grine DR, Arkfeld TE (1963) The use of compressional and shear acoustic amplitudes for the location of fractures. In: SPE of AIME, 38th Ann Fall Mtg, New Orleans, Louisiana paper SPE 723

Nelson RA (2001) Geologic analysis of naturally fractured reservoirs, 2nd edn. Gulf Professional Publishing, Houston, p 332

Omran MA, El Sharawy MS (2014) Tectonic evolution of the Southern Gulf of Suez, Egypt: a comparison between depocenter and near peripheral basins. Arab J Geosci 7(1):87-107
Plaziat JC, Montenat C, Barrier P, Janin MC, Orszag-Sperber F, Philobbos E (1998) Stratigraphy of the Egyptian syn-rift deposits: correlations between axial and peripheral sequences of the north-western Red Sea and Gulf of Suez and their relations with tectonics and eustacy. In: Purser B H, Bosence DWJ (eds) Sedimentation and Tectonics in Rift Basins. Red Sea-Gulf of Aden, pp. 211-222

Roehl PO, Choduette PW (1985) Carbonate petroleum reservoirs. Spring-Verlag, New York, p 622

Said R (1962) The geology of Egypt. Elsevier publishing cc, Amsterdam, p 377

Schlumberger (1989) Log interpretation principles/applications, p 228

Schutz KI (1994) Structure and stratigraphy of the Gulf of Suez, Egypt. In: Landon SM (ed) Interior rift basins: American Association of Petroleum Geologists Memoir 59:57-96

Serra O (1986) Advanced interpretation of wireline logs. Schlumberger copyright, p 295

Serra O (1988) Fundamental of well-log interpretation. Developments in Petroleum Science. Elsevier Science Publishers, Amsterdam

Shanks RT, Kwon MR, Devries MR, Wichmann P (1976) A review of fracture detection with well logs. Soc Pet Eng AIME 6159:491-507

Sibbit AM, Faivre O (1985a) The Dual Laterolog response in fractured rocks, SPWLA, $26^{\text {th }}$ ann. Log. Symp. Trans, Paper T

Sibbit AM, Faivre O (1985) The Dual Laterolog response in fractured rocks, SPWLA. In: 26th Ann Log Symp Trans Paper T

Steckler MS, Ten Brink US (1986) Lithospheric strength variations as a control on new plate boundaries: examples from the Arabian Plate. Earth Planet Sci Lett 79:120-132

Tamsett D (1984) Comments on the development of rifts and transform faults during continental breakup; examples from the Gulf of Aden and northern Red Sea. Tectonophysics 104:35-46

Tezcan SS, Keceli A, Ozdemir Z (2006) Allowable bearing capacity of shallow foundations based on shear wave velocity. J Geotech Geol Eng 24:203-218

Thompson LB (2000) Fractured reservoirs: integration is the key of optimization. Disting Author Ser SPE 56010:52-54

Tromp SW (1950) The age and origin of the Red Sea Graben. Geol Mag 87:385-392

Uyanik O (2010) Compressional and shear-wave velocity measurements in unconsolidated top-soil and comparison of the results. Int J Phys Sci 5(7):1034-1039

Wyllie MRJ, Gregory AR, Gardner GHF (1956) Elastic wave velocities in heterogeneous porous media. Geophysics 21(1):41-70

Wyllie MRJ, Gregory AR, Gardner GH (1958) An exprimental investigation of factors affecting elastic wave velocities in porous media. Geophysics 23(3):459-493

Younes MA (2003) Hydrocarbon seepage generation and migration in the southern Gulf of Suez Egypt: insights from biomarker characteristics and source rock modeling. J Petrol Geol 26(2):211-224 